\title{
Teaching Religious Tolerance Through Social Studies Education Based on Multicultural Approach
}

\author{
Anisca Dyah Permata Sari \\ Department of Social Science \\ Universitas Negeri Yogyakarta \\ Yogyakarta, Indonesia \\ aniscadyahpermatasari.2017@student.uny.ac.id
}

\author{
Setyabudi Indartono \\ Faculty of Economy \\ Universitas Negeri Yogyakarta \\ Yogyakarta, Indonesia \\ setyabudi_indartono@uny.ac.id
}

\begin{abstract}
This article describes a form of multicultural based on education with various aspects of diversity. Theological science taught tends to be just to strengthen the faith and attainment of heaven without being accompanied by dialogue with other religions. This condition sometimes leads to intolerance. Whereas there needs to be a philosophical-paradigmatic reorientation about how to build a diversity of multicultural, humanist, dialogue-persuasive, contextual, substantive and socially active societies. In the postmodern era today, besides religious education, it should social studies education used as a place to foster mutual tolerance and maintain harmony. This is because Social Studies is directly related to social and real problems. Furthermore, there are also done in everyday life. This paper is conducted to find out the multicultural based education on the character of religious tolerance with one approach that can be combined with socio-cultural values. This approach is a synthesis in order to deal with the seeds of intolerance that have begun to grow in the young generation of this nation. This article was written to provide an overview of teaching religious tolerance through social studies education based on a multicultural approach. The method in this study is library research or literature review.
\end{abstract}

Keywords- religious tolerance; social studies education; multicultural

\section{INTRODUCTION}

Important, strategic, and determinative factor for society is education. Progressing and retreating the quality of civilization of a society or nation depends heavily on the quality of education organized by the community. Education is all the efforts of adults in association with children. Discourse on multicultural education is growing along with the ongoing flow of democratization in the life of the nation, which has implications for strengthening civil society and respect for human rights. Multicultural education is a concept or idea as a set of believe and an explanation that recognizes and assesses the importance of cultural and ethnic diversity in shaping lifestyles, social experiences, personal identities and educational opportunities for individuals, groups and countries.

James Banks defines multicultural education as education for people of color. It means that multicultural education wants to explore differences as a necessity (sunnatullah), then how we can address these differences with tolerance and egalitarian spirit. As a developing country, making education as one of the strategic means in developing national identity is a good, relatively precise step, and promises that education is appropriate and seems compatible to build our nation is a multicultural-based education model. In this regard, multicultural education offers an alternative through the implementation of strategies and concepts of education based on the utilization of diversity in the community, especially in the diversity of ethnicity, culture, language, religion, social status, gender, ability, age, and race [1].

Diversity often results in conflicts between groups because they still attach importance to each other's ego. It does not only occur in the outside community but in the education level unit in schools, there is still a lack of harmony in diversity. The character of religious tolerance which is a manifestation of tolerance in the form of behavior respects differences in ethnicity, religion, race, language, between religious groups, gender, and even different opinions. In school, the character of tolerance becomes one of the important characters to be instilled. The character of tolerance can create awareness and acceptance of diversity in life in order to realize harmony among people during differences. However, it should be noted that lately it is far from the hope of humanity that promoting the values of social justice, security, peace, brotherhood and harmony, with rampant discrimination, social, religious, political, economic, cultural and educational conflicts, are increasingly rampant in this country.

The most important thing that needs to be questioned is how can the solution be minimized? According to Achmad Fedyani in the journal of Ruslan, it is stated that if the problem was examined using a social anthropology approach, anarchic actions performed by a certain group of people / community over others would be contrary to fair and civilized human values, which is one of the five basic foundations of the Indonesian (Pancasila). Therefore, in this case, it is necessary to teach tolerance through social studies education based on a multicultural 
approach to instill values of mutual respect and respect for differences [2].

\section{LITERATURE REVIEW}

\section{A. Religious Tolerance}

From the Latin word tolerantia means meaningfulness, relief of patience and tenderness. UNESCO defines tolerance as mutual respect, mutual acceptance, mutual respect amid cultural diversity, freedom of expression and human character. Whereas in general the term tolerance refers to an open, airy, voluntary and gentle attitude [3]. So, humans as social beings who have relationships with other humans must certainly be arranged in accordance with existing norms and mutually agreed to realize harmony in the form of harmony and peace. Religion as a guide to sacred behavior directs adherents to respect and respect, but often the reality shows the opposite, adherents of religion are more interested in emotional aspects. In this case Khami Zada revealed that religion can lose its substantial meaning in answering humanitarian questions, namely when religion no longer functions as a living guide capable of producing spiritual and objective comfort in all aspects of human life or in Karl Marx's terms when religion has become an opium for society [26]. That kind of thing that is being experienced by the Indonesian people facing the challenge of shifting religious functions [4]. The attitude of religious tolerance should have been implemented early on starting from the family, community and school environment so that early respect and respect are accustomed to being small.

\section{B. Social Sciences}

According to [5] journal in Nadir said that social studies can be interpreted by activities in studying or can be called the study of society. In this case the activity of studying the community, the teacher can do from a variety of social perspectives, such as studies through teaching history, geography, economics, sociology, anthropology of politicsgovernance, and simplified aspects of social psychology to achieve learning goals. All aspects of history, geography, economics, sociology, politicalgovernmental anthropology, and social psychology are expected to merge into one. Of all the disciplinary aspects of science applied in daily life by applying from various aspects of the science. In social studies learning the state of the community that is fast developing with a variety of multicultural communities and viewed from different backgrounds from ethnicity, race and religion, social studies learning is required to be able to fuse these differences and teach values to be good citizens.

\section{Multicultural}

HAR Tilaar says that multiculturalism is a concept with all the civilizations carried out within the education unit, therefore the process of education is a process of civilization, so multicultural society can be created through an educational process. Education and civilization are a process of forming the character of the nation and citizens [25]. Multicultural education is education based on multiculturalism. Whereas Tobroni et al, in his book Citizenship Education states that multicultural education can be seen in three things, namely: 1) multicultural education as a concept or idea, 2) multicultural education as a movement, and 3) multicultural education as a process while all three it must be interrelated with each other [27]. Therefore, multicultural education requires in-depth study, perfect filling and enrichment of concepts, and careful application so that the implementation is right on the target without any sense of discrimination [6]. Meanwhile, Howard argues that multicultural education provides multicultural competence [4]. In the early days of students' lives, time was spent in their respective ethnic and cultural areas. Mistakes in transforming values, aspirations, etiquette from certain cultures, often have an impact on tribal primordialism, religion, and excessive class. This factor causes the emergence of hostility between ethnic groups and groups. Through multicultural education from the beginning, it is expected that the child will be able to accept and understand cultural differences that affect the usage differences, namely the way individuals behave, folkways, namely the habits that exist in society, mores, namely the behavior in the community, and customs, namely customs in a community. With multicultural education students can accept differences, criticism, and have a sense of empathy, tolerance for others regardless of class, status, gender, and academic abilities [7]. Therefore, it is expected that students understand the diversity that exists, that they must respect and respect each other. These differences are intended to understand and interpret the meaning of differences in unity such as the meaning of Unity in Diversity to be carried out in daily life as a social being.

\section{EPISTEMOLOGY AND IMPLICATIONS}

\section{A. Embedding the Character of Religious Tolerance}

Mahmud argues that tolerance is an attitude and action that respects differences in religion, race, ethnicity, opinions, attitudes and actions of others who are different from themselves. Tolerance is called an essential factor for peace. The absence of a character of tolerance can lead to unexpected conflict because tolerance is basically based on the attitude of the chest to other people by paying attention to the principles that are held by themselves. Tolerance is important to instill because within tolerance, there are points of reflection expressed by Tillman, among others, tolerance as a method of achieving peace, tolerance is open and receptive to the beauty of differences, tolerance of respect for individuals and their differences, removing tensions caused by ignorance, giving the opportunity to discover and removing stigma related to diversity, tolerance to respect each other through understanding, tolerance is compassion, tolerance for the inconvenience of life by allowing differences and allowing others to feel [8]. 
Character values and national culture include the character of tolerance. Tolerance towards plurality is a necessity to build a unified whole. In general, tolerance is fair, objective, and permissive towards people whose opinions, practices, races, religions, nationalities, and so forth. Being tolerant is an attitude that is free from bigotry, accepting and appreciating differences. The character of tolerance will shape society into people who are friendly, so that it becomes a person who is pleasant, peaceful and opens the door to others [9].

When linked to education, character education is a planned effort to make students know, care, and internalize values so that students behave as human beings. In another formulation, it can be defined that character education is a system of planting behavioral or character values to learn citizens which includes:

1. Knowledge that is how someone has knowledge about character values that must be possessed by every human being

2. Awareness or willingness that is a human attitude that has a sense of self-awareness of every action and good and bad behavior every time he does, it will get a reply

3. Actions to perform the values, both towards God Almighty, oneself, others, environment, and nationality so that they become our human beings.

The definition mandates that with all the differences in the Indonesian nation, education in Indonesia aims to make learning citizens have four main characters, namely religious people, humans as individuals, social humans and humans as citizens of the nation [4]. As Azyumardi Azra affirms, it is not something that is taken for granted but must be pursued through a multiculturalist educational process, namely education for all, and education that gives serious attention to the development of tolerant attitudes, respect for ethnic, cultural and religious differences, and gives civil rights belong to minority groups [9]. Thus, multicultural education in this context is defined as an educational process that gives equal opportunities to all children of the nation without discriminating treatment due to ethnic, cultural and religious differences, which gives respect for diversity, and which gives equal rights to ethnic minorities, in efforts to strengthen unity, national identity and national image in the eyes of the international community [10].

Character education efforts in developing values of tolerance and social care must be done in various activities and the environment. In a school environment, tolerance and social care are important and fundamental values to develop. The school is agreed as a form of social system which consists of components of the school community with various backgrounds; economy, family environment, habit, religion even different desires, ideals and interests.
With these differences, it is not impossible if conflicts of interest occur which also lead to conflicts of interest. Therefore, efforts are needed that are intentionally and continuously directed to develop tolerance and social care for students, so that they get meaningful exercises and experiences related to these aspects, to then be brought and developed in the community which is more diverse. By paying attention to the school's vision, mission, and objectives, fostering the values of tolerance and social care are characterized by an emphasis on the dimensions of character, behavior, attitudes, and other affective matters. Character education does not only have an integrative dimension, in the sense of strengthening the intellectual moral of students so that they become strong and enduring individuals, but also curative both personally and socially [11]

\section{B. The Role of Social Studies Education}

According to Pramono, it is stated that social studies basically learn about social knowledge, various aspects of social conditions, and social behavior in the community in order to be able to become a good society [17]. Social Studies is a subject found in the school curriculum, which studies relationships between people and is seen as most important in developing responsible citizens. Social Studies is an educational program that integrates the concepts of science, social, humanities, values, ethics, economics, socio-cultural and environmental past, present and future so that Social Studies will be more successful and efficient. In its implication, social studies learning does not only understand social knowledge but can also apply social attitudes in everyday life, so that in learning, it is expected that students can be socially good with their peers in the learning process without choosing friends, especially in group activities, can appreciate differences in background and culture.

In learning activities, interactions between students with one another, interaction between students and teachers, as well as interaction between students and learning resources occur. The phenomenon that has spread among the people lately is due to the changes in lifestyle that apply as a result of the agitation of the communication and information systems delivered by the nation which makes it easy for anyone to access. This causes every community to be individualistic, so that it dissolves a sense of caring for the social, trapped in a hedonistic life which ultimately strengthens the fatigue of idealism and fighting spirit and agnostic attitude so that sometimes we often meet among adolescents who have an uncaring attitude towards the surrounding the values of tolerance let alone fellow human beings who are both one religion rarely show tolerance, especially with different religions. Moreover, almost every school is dominated by certain ethnic or religious groups which sometimes affect social interaction between the majority and the minority. Suppose the 
school is dominated by most Muslims with a very small index of non-Muslim minorities Hambali [12].

In the journal of Rofiqoh, it is explained that in the social studies curriculum, including the learning process, it must be initiated and based on the nature and character of students, not merely material oriented [5]. The essentialism approach is time to be modified with the theory of social reconstruction which refers to the theory of interaction education so it can be stated that the socio-cultural approach between school citizens is emphasized so that students are able to interact with others and not become selfish individual beings.

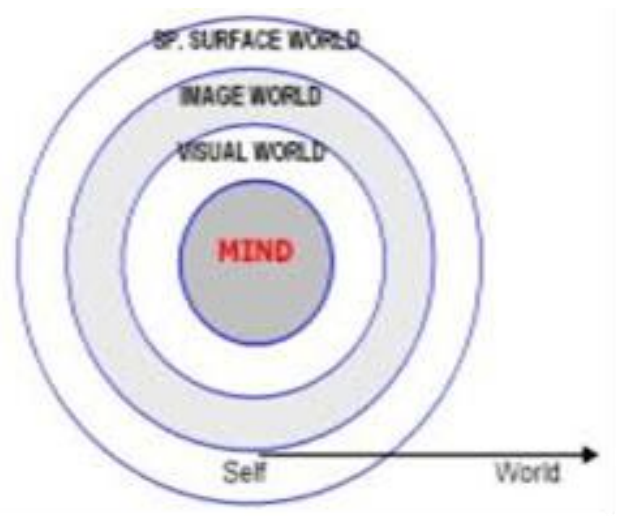

Fig. 1. Recapitulation Theory Cognitif Human Herbartian model [13]

The Herbartian philosophy system according to social sciences experts is as a "philosophical foundation in the social studies movement as a whole" since the beginning of its conceptualization, both in America [14]. Therefore, the learning system of social science is not only influenced by the social system, but can be obtained from real experience, the concept of a theory is then practiced in life which includes scientific conceptions and predispositions cultural and institutional and integrates with practical needs schools [15].

\section{Multicultural Education}

The phrase of "being a democratic and responsible citizen" shows the determination to conduct multicultural education. As a new discourse, the terminology of multicultural education is not very clear and there is still debate among experts. Hilda Her Nandez stated that multicultural education is a perspective that recognizes the political, social, and economic realities experienced by each individual in a complex and culturally diverse human meeting, and reflects the importance of culture, race, sexuality, gender, religion, socio-economic status, and exceptions in the education process [16].

Bank states that multicultural education includes at least three things: ideas or concepts, a reform movement in the field of education, and a process [1].
Multicultural education incorporates the idea that all students regardless of their gender, social class, ethnicity, racial, or cultural characteristics should have equal opportunities to learn in school. Another important idea in multicultural education is that some students, because of these characteristics, have a better chance to learn in schools as they are currently structured than do students who belong to other groups or who have different cultural characteristics.

Another expert whose opinion needs to be considered is Sleeter \& Grant, and Smith, it is defined that multicultural education as a progressive approach to transform education that holistically provides criticism and shows weakness, failure, and discrimination that occur in education [17]. According to Nieto in Zamroni multicultural education is a form of education that relies on social justice, equality of education and a dedication to provide learning experiences where all students can achieve optimal development. In general, multicultural education is understood as an education reform that promotes social justice for all groups in society regardless of the diverse identity and background of students in order to achieve educational goals optimally [18].

Moule stated there are 4 components that need to be present in multicultural education, namely awareness, attitude, knowledge, skills [19]. In the awareness that we are expected to be able to feel our own reactions to different people, the components of attitude need to increase multicultural competencies to individually make their beliefs and values about other cultures, that there are many diversity that we deserve to appreciate for these diverse differences, so the need for a component of knowledge to respect and respect each other is important to have because of values and beliefs and also the essence. The views of others influence our attitude, and we sometimes don't understand it. There are many people who are often prejudiced towards strangers while the knowledge component becomes important for improving multicultural competencies. Components of skills need to handle communication, verbal signals and nonverbal signals that tend to vary between cultures. With these four components, it can interpret the value of multiculturalism.

\section{Epistemology of Social Education Objectives Sociocultural Values Perspectives}

The development of the globalization era that is increasingly spreading to various countries without exception Indonesia indirectly influences the existing side of life in the region. Modernization can result in humans becoming secularistic-materialistic [9]. For this reason, social studies learning that covers all aspects of social, cultural, economic and political is expected to be able to answer the challenges of changing times to shape its citizens to be good and have character in the young generation. The demands of modernity and globalization require scientific social studies and seriously involve various approaches; one of which is through a multicultural 
approach by teaching sociocultural values which contain elements of justice in diversity and not discriminating between tribes, races, religions and social cultures. As an example of this recent case, discriminatory actions are not new things in the public domain, openly discriminatory actions are taken without thinking about the impact both physically and psychologically for the victim.

In relation to social studies learning, an important thing that must be applied in the planting of values of religious tolerance is that it can present material, for example in social studies on social interactions of teaching materials developed by teachers by providing understanding to students that in religious life with different beliefs and beliefs -different is required to always instill a tolerant attitude, namely an attitude of mutual respect and respect and giving freedom to followers of other religions to practice religion without any mutual interference with one another, planting tolerance values can be done with learning media and can be practiced directly so not only Skedar refers to what the teacher has given but seeks to actively apply in everyday life, for example, attitude to greet and greet anyone without distinguishing religion Mokodenseho [20].

In the journal written by Rohman, it is stated that in practice, education can integrate socio-cultural values and multicultural values first, namely the internalization of sociocultural values in the implementation of education departing from the heterogeneity of learning derived from ethnic, religious, and culture [21]. For example, in a class, it is possible to consist of students from different ethnic, cultural and religious backgrounds. Thus, an educator in conducting his duties should be based on social and cultural values to accommodate all the needs of students. Second, the internalization of multicultural values is closely related to the ethnic, cultural, and religious composition of students in a school. For example, in public education institutions, such as high schools certainly have diverse students. The education presented must lead them to be inclusive, tolerant, and not anti-difference individuals, to be social beings who are good and sensitive to the surrounding environment so that in practice in the community, they will not be surprised if they encounter differences, because basically all it departs from diverse differences but how it can respond to such diversity into a unified whole and create a sense of security and comfort for others even with different backgrounds [21]. Oppressive policies in schools usually come in the disguise of maintaining the status quo [22]. Alas, the concept of cultural pluralism is many times superseded by this. Gordon indicated that "cultural pluralism involves giving and taking and, more importantly, the sharing of and mutual respect for ideas, customs and values" [23]. Cox opined that "pluralism refers to a two-way learning and adaptation process in which both the organization and entering members from various cultural backgrounds change to some degree to reflect the cultural norms and values of the other" [24]. We have chosen Cox and Gordon's definition of cultural pluralism to illustrate how multiculturalism addresses the social, political, and economic effects that diversity has on communities and on society as a whole, because here the focus of discussion in the field of cultural socialism is seen very much the impact of pluralism that occurs as for example social inequality between the majority and the minority, which causes intolerance conflict. The majority feel powerful and have the right to what they want without thinking of a minority. The teaching of social science with a multiculturalism approach is important to reduce intolerance, as an example of a small thing that does not discriminate between the majority and the minority.

\section{E. Implications of Social Education Based on Socio-cultural Values}

As an approach used in the implementation of education, socio-cultural values will have a different impact in achieving the goals of education in social studies subjects which are closely related to social life in daily life will be very useful in shaping the character to be a good citizen. Social studies education is to provide stimulus to humans in order to have a humanistic nature, a good society and become social beings who are sensitive to the surrounding life and able to appreciate every diversity that is often encountered. In the journal of Farisi specifically in the dynamics of social epistemology, the concept and model of competency-based education is not a new discourse [15]. Since Social Studies became the content of the school curriculum in the United States in the late 19th century, it has been oriented towards achieving certain competency standards [15]

Orientation on achieving these competencies has been consistently maintained since the beginning of its growth by the Committee on Social Studies (CSS) until now by the National Council for Social Studies (NCSS) [14]. While the current curriculum by adopting the 1975 curriculum is oriented towards the development of social studies directed at achieving socio-cultural competence, namely self-awareness as a human being who must be able to live in an environment full of functional and reciprocal relationships between himself and his environment, and be able to utilize the environment for his life as human [14]. In the curriculum, the orientation of the development of social studies is directed not only at achieving socio-cultural competencies, but also intellectual-scientific competencies, namely the ability to develop critical and creative ways of thinking about human relations with their environment. When a teacher explains courtesy to students using the right socio-cultural approach, it will facilitate the achievement of educational goals optimally. Besides being able to create social justice, 
the internalization of socio-cultural values can create social harmony within the scope of educational institutions, considering that in every school there must be a lot of diversity in it. For example, when learning in groups how students can blend in with one another without differentiating religion, social status or race here is the task of a teacher to be a facilitator to bridge so that students are able to socialize well. This activity is suitable to be applied to classes consisting of students of diverse ethnicity. Thus, students as subjects of learning will have a tolerance, respect for differences, and stay away from prejudice to others [15].

\section{CONCLUSION}

Character values and national culture have included the character of tolerance. Tolerance towards plurality is a necessity to build a unified whole. In general, tolerance is fair, objective, and permissive towards people whose opinions, practices, race, religion, nationality, and so on. Being tolerant is an attitude that is free from bigotry, accepting, and appreciating differences. One thing that can be done is to use a socio-cultural approach, namely the internalization of sociocultural values in the implementation of education, departing from the heterogeneity of learning derived from ethnic, religious, and cultural diversity and multicultural values closely related to the ethnic composition, culture and religion of the students at school. The orientation of the development of social studies is directed not only at achieving socio-cultural competencies, but also intellectual-scientific competencies, namely the ability to develop critical and creative ways of thinking about human relations with their environment. When a teacher explains courtesy to students using the right socio-cultural approach, it will facilitate the achievement of educational goals optimally. Besides being able to create social justice, the internalization of sociocultural values can create social harmony within the scope of educational institutions, considering that in every school there must be a lot of diversity in it.

\section{REFERENCE}

[1] Banks, James A."An Introduction to Multicultural Education'. Boston: Allyn \& Bacon, pp 3, 2001.

[2] Ibrahim, R.'Pendidikan Multikultural: Upaya Meminimalisir Konflik Dalam era Pluralitas Agama. ElTarbawi Jurnal Pendidikan Islam, Vol 1, pp. 121-122, 2008.

[3] Casram." Membangun Sikap Toleransi Beragama Dalam Masyarakat Plural". Wawasan: Jurnal Ilmiah Agama dan Sosial Budaya Vol 1 No 2, pp. 188, 2018

[4] Suryana, Y dan Rusdiana, A. "Pendidikan Multikultural Suatu Upaya Penguatan Jati Diri Bangsa (Konsep-PrinsipImplementasi). Bandung: CV Pustaka Setia, 2015.

[5] Rofiqoh L \& Suherman A. "Peran Pendidikan Ilmu Pengetahun Sosial Dalam Membentuk Karakter Pluralis Siswa Di Mts N 11 Cirebon", Jurnal Edueksos, Volume VI No 2, pp. 137, 2017
[6] Wihardit K."Pendidikan Multikultural:Suatu Konsep, Pendekatan Dan Solusi',. Jurnal Pendidikan, Volume 11, Nomor 2, pp. 96-105, 2010.

[7] Hanum F. "Implementasi Model Pembelajaran Multikultural Di Sekolah Dasar Di Propinsi Daerah Istimewa Yogyakarta'. Artikel Multikultural-Stranas, pp. 6, 2009.

[8] Sari, D.P, \& Suyanto, T. "Penanaman Karakter Toleransi Pada Siswa Reguler Dan Siswa Berkebutuhan Khusus Melalui Pembelajaran PPKn SMPN 4 Sidoarjo", Kajian Moral dan Kewarganegaraan,Volume 05 Nomor 02, pp.366, 2017.

[9] Azra, Azyumardi. "Pendidikan Islam: Tradisi dan Modernisasi menuju Millinium baru", Jakarta: Kalimah, 2001.

[10] Rosyada, D. 'Pendidikan Multikultural Di Indonesia Sebuah Pandangan Konsepsional ', Sosio Didaktika, Vol. 1, No. 1, pp.3-4, 2014

[11] Sari, Y.M. " Pembinaan Toleransi Dan Peduli Sosial Dalam Upaya Memantapkan Watak Kewarganegaraan (Civic Disposition) Siswa", JPIS Jurnal Pendidikan Ilmu Sosial Volume 23 No 1, pp. 17-18, 2014.

[12] Hambali K. M, \& Haled MHM. "'Toleransi Beragama Dan Amalannya di Malaysia: Rujukan Kepada Artikel 11 Perlembagaan Persekutuan Malaysia ', Jurnal Usuluddin, Vol 27, pp. 88, 2008.

[13] Brassard, L. "Recapitulation Theory of Cognition". http://www.webnow.com/ herbart. [29-102002]. 2001

[14] Saxe, D.W.Social Studies in Schools: A History of The early Years. New York: State University of New York Press. 2001.

[15] Farisi. "Struktur Kompetensi Ilmu Pengetahuan Sosial Sekolah Dasar Dan Pengorganisasian Pengalaman Belajar Siswa '. Interaksi Jurnal Pendidikan, Vol 3, No 3, pp. 14, 2007.

[16] Mahfud, C."Pendidikan Multikultural”. Yogyakarta: Pustaka Pelajar. 2010.

[17] Zamroni. 'Pendidikan Demokrasi Pada Masyarakat Multikultur’'. Yogyakarta: Ombak (Anggota IKAPI). 2013.

[18] Sudrajat. Revitalisasi Pendidikan Multikultural Dalam Pembelajaran'. Jurnal Pembangunan Pendidikan: Fondasi dan Aplikasi,Volume 2 Nomor 1, pp. 86, 2014.

[19] Moule, Jean. Cultural Competence: A primer for educators. California: Wadsworth/Cengage, Belmont. 2012.

[20] Mokodenseho S \&Wekke I S. "Toleransi Beragama Dan Pembelajaran Agama Islam: Harmoni Masyarakat Minoritas Muslim Manado ". Prosiding Seminar Nasional \&Temu Ilmiah Jaringan Peneliti, pp. 70-71, 2017

[21] Rohman M \& Hairudin. ' Konsep Tujuan Pendidikan Islam Perspektif Nilai-nilai Sosial-kultural '’. Al-Tadzkiyyah: Jurnal Pendidikan Islam, Vol 9, pp. 21-34, 2018.

[22] Ferguson, A. A. Bad boys: Public school in the making of black masculinity. Ann Arbor: The University of Michigan Press. 2001.

[23] Gordon, M. M. Human nature, class, Bahleshndịits ANe(2001), “An Introductio York: Oxford University Press. 1978.

[24] Cox, T. H. Cultural diversity in organizations: Theory, research, and practice. San Francisco: Berrett Koehler Publishers. 1994

[25] Tilaar, HAR, "Multikulturalisme tantangan-tantangan global masa depan dalam transformasi pendidikan nasional", Jakarta: Grasindo, 2004.

[26] Khamami Zada, "Tantangan Kehidupan Beragama", KOMPAS, 2002

[27] Tobroni, "Pendidikan Kewarganegaraan, Demokrasi, HAM, Civil Soxiety, dan Multikulturalisme", Yogyakarta: Nuansa Aksara: Pusapom Malang, 2007. 